\title{
PREVENTING THE EXTINCTION OF IGBO LANGUAGE
}

\author{
Ifeanyi S. Odinye \& Ifeoma E. Odinye
}

\section{Introduction}

Language is an ethnic identity. It should be handled seriously. The people who loose their language have lost their identity. Language is an indispensable tool for human communication and national development. Most human activities make use of language. Man is not complete without language. This statement is affirmed by Eva Engholm as sited in Nwadike (2003:13) that:

Language is the key to the heart of the people. If we lose the key, we lose the people. If we treasure the key and keep it safe, it will unlock the door to untold riches, riches that cannot be guessed it from the other side of the door.

Nigeria is a West African black nation with a population of about 140 million people. It covers an area of 923,766 square kilometers, with over 200 different ethnic groups. Nigeria is politically composed of 36 States and Abuja, the Federal Capital Territory. It is estimated that over 400 languages are spoken in Nigeria (cf. Crozier and Blench (1992), Grimes (2000), Heine and Nurse (2000)). In some areas of Nigeria, ethnic groups speak more than one language. The official language of Nigeria, English, the former colonial language, was chosen to facilitate the cultural and linguistic unity of the country. The major languages spoken in Nigeria are Hausa, Igbo, Yoruba, Fulfulde, Kanuri, Ibibio. Igbo language is spoken in Anambra, Eboyi, Enugu, Imo States and parts of Delta and Rivers States.

The constitution and national policy in education recognized three major languages, Hausa, Igbo and Yoruba, only Igbo was being threatened by extinction. UNESCO report on endangered indigenous languages says the Igbo language faces risk of possible extinction in the next 50 years if nothing is done to revive the language. Some people do not think it is an overstatement to refer to Igbo language as being endangered and facing threats of extinction 
going by its declining level of acceptability amongst the Igbo people. It is disheartening to see a language that is supposed to be an insignia, a trademark and a common identity amongst the Igbo people rather than being proudly flaunted as treated with so much scorn and disdain. We seem to have jettisoned the intergenerational transmission of the Igbo language is exchange for western trends, which include the English language with its obvious linguistic threats.

The forecast of the UNESCO on the possible extinction of Igbo language in the next 50 years is becoming widely accepted by the Igbo people both home and abroad. An Igbo woman living in America has this to say:

Yes, I agree. A lot of our families do speak English to our kids including myself. Charity begins at home. Especially we that live in the western world have adhered to the society we are in and speak English to our kids. Look at the Yoruba people in America, they speak Yoruba to their kids and teach them their culture. I have just started speaking Igbo to my kids. God help us.

This is a proof that Igbo people are the cause of the decline of Igbo language development. This study is divided into five sections: The introduction, the language attitude of the Igbo people, the degree of Igbo language endangerment, saving Igbo language from extinction and the conclusion.

\section{The Language Attitude of the Igbo People}

Bainbridge (1994:400) defines attitude as "the positive or negative evaluation of an object with anything, tangible or intangible, capable of being the object of an attitude". Othmen and Bashir (2000:449) while quoting Johnson (1973:167) opines that community language attitudes denote the positive-negative evaluations of individual languages or group of languages, with regard to such dimensions as loyalty, prestige, utility, cognancy or aesthetics. Wassink (1999:57) claims that language attitude can be overt or covert. 
The Igbo people portray negative attitudes toward their language (cf. Duruaku 2004:102, and Irono 2005:31). In support of the above statement, Eme (2004:304) says:

Some Igbo parents, especially the literate ones, do not speak Igbo to their children even at home. In some cases, the parents ban their children from using Igbo to communicate among themselves.

She went further to say that such parents do not feel ashamed to tell anybody that cares to listen that their children do not understand/speak Igbo. In fact, they feel elated at their children's achievement- mastering the 'prestigious' English language and dawning the 'awkward' Igbo language.

Most Igbo parents do not take delight in transferring Igbo to their children. It is in line with this that Nwadike (2008:39-40) observes that:

Many Igbo parents do not want their children to speak Igbo. Once, a mother at the University of Nigeria, Nsukka, asked her children to desist from speaking that useless language (Igbo). This class of parents gets offended with teachers who teach Igbo as a subject to the children.

Igbo language cannot be more important than its speakers' value on it. In other words, it is the speakers of Igbo language, (that is the Igbo people), that can determine how important Igbo language becomes. If they have a positive attitude toward Igbo language, Igbo will be important and vice versa.

There are certain factors that cause Igbo people to have negative attitude toward their language. Some of these factors include among others:

\section{Education}

Education can trigger off either positive or negative attitudes toward language(s). According to Chumbow (1990:63), language is the indispensable medium for the education and treming of skilled 
manpower. Based on the above statement, because English language is the language of education, government, trade, etc in Nigeria, Igbo people develop favourable attitude toward English language. Igbo people abandon the use of Igbo language from primary school to higher institution because the language of instruction is English language. By so dosing, their love for Igbo language dies gradually.

\section{Government Policy on Language}

It is observed that when the government of a country formulates a language policy which recognizes one language as the official language of that nation, the given language will definitively attracts favourable attitudes from the people since it services as a means of carrying out official functions. This kind of policy favours one language against the other. This is the cause of English language use in Nigeria. It dominates the indigenous language which includes the Igbo language.

\section{Globalization}

Globalization is a powerful thrust in the current world politics, and it is an important factor in determining whether or not a language thrives. Globalization indirectly discourages diversity and encourages homogenization. Invariably, it suggests speaking the same kind of language, which English is that language. Fishman (2001:6), "In our day and age, it is definitely the globalization of pan-western culture (and pop-consumer culture in particular) that is the motto of language shift. And since American dominated globalization (she) has become the major economic technological and cultural thrust of worldwide modernization and westernization, efforts to safeguard threatened languages (and therefore; contextually weaker language) must oppose the very strongest processes and powers. Because Igbo people live in a globalize world, they are forced to the effect of globalization.

Despite the above factors that cause people to have positive attitude toward a foreign language and negative attitude toward their language, Igbo people do not value their language. This is confirmed by the existence of other indigenous languages in Nigeria, like Yoruba and Hausa that face the same factors yet cherishing their languages. 


\section{The Degree of Igbo Language Endangerment}

Language endangerment can be defined as a condition whereby the socio-economic, political, technological, cultural and religious ecologies have altered to a point where some language species cannot survive or thrive in them.

According to Aikawa in UNESCO (2001), endangerment can be ranked on a continuum, from stability to extinction. Six degrees of endangerment may be distinguished with regards to intergenerational language transmission. They are:

1. Extinct: There is no one who can speak or remember the language.

2. Critically Endangered: The youngest speakers are in the great-grandparents' generation and the language is not used for everyday interactions.

3. Severely Endangered: The language is spoken only by grandparents and other generations, while the parent generation may still understand the language they typically do not speak it to their children or among themselves.

4. Definitely Endangered: The language is not learnt as the mother tongue by children in the home. The youngest speakers are thus of the parental generation. At this stage, parents may still speak their language to their children, but their children do not typically respond in the language.

5. Unsafe: Most children speak their parental language as their first language but this may be restricted to specific social domains such as the home where children interact with their parents and grandparents. 
6. Safe: The language is spoken by all generations. The intergenerational transmission of the language is uninterrupted.

There is no doubt whether Igbo language is endangered or not. It is good to know the degree of the endangerment at present. The degree of Igbo language endangerment is in between "Definitely Endangered' and 'Unsafe'. It is frightening to note that about 50 percent Igbo children cannot speak Igbo language. Every parent is making effort to see his child speak English language and none encourages his child to speak Igbo language. There is no place where speaking of Igbo language is encouraged. It is not used in government even in Igbo land, schools, churches, meetings, campaigns, conversations, not even at homes. It is noted with that it is sad that Igbo language becoming extinct at on alarming rate, with little or no effort from the people and government to curb the negative trend.

\section{Saving Igbo Language from Extinction}

Igbo language would possibly be extinct in the next 50 years if the current rate of decline in its use is sustained. In the face of the dying Igbo language, it will be a sin to do nothing. Igbo language will surely die unless we do something about it. The future generation will not forgive us if we allow Igbo language to die. The time to do something is now.

We can save the Igbo language from extinction if we do the following:

- Love Igbo language and culture

- Have interest in saving Igbo language.

- Speak Igbo language at all times.

- Encourage the younger generation to learn Igbo language

- Provide scholarships for students and teachers of Igbo Language.

- Use Igbo language in media: radio, television and newspapers.

- Make Igbo language a compulsory subject for admission into higher institution in Igboland. 
- Pass a bill to encourage the use of Igbo language in government of Igboland.

- Encourage the reading of Igbo written materials at churches, schools, homes, etc.

- Discourage people especially the younger generation from speaking English and other languages

\section{Conclusion}

Language is very important to man. We make use of language almost at all times even when we think or dream. Language should not be allowed to die since it is very important to man. If other languages in the past can die, Igbo language can die if nothing is done. When the above recommendations and more are implemented, Igbo language will be saved from extinction. 


\section{References}

Aikawa, N. (2001). "UNESCO's Programme on Languages" In Conference Handbooks on Endangered Languages of the Pacific Rim. Osaka: Endangered languages of the Pacific Rim Project, 13 - 14.

Bainbridge, W.S (1994). "Social Psychology". In R.E Asher and J.M.Y. Simpson (eds.) The Encyclopedia of Language and Linguistics. Oxford: Pergamon Press. Vol. 71. pp. 3998-4004.

Chumbow, B.S. (1990). "The Place of the Mother Tongue in the National Policy on Education". In E.N. Emenajo (ed.)

Multilingualism, Minority Language and Language Policy in Nigeria. Agbor: Central Books Limited. Pp. 61-72.

Crozier, D.H. and R.M. Blench (1992). "An Index of Nigerian Languages" (eds.). Second Edition. Dallas: Summer Institute of Linguistics, Inc.

Duruaku, C. (2004). "Folktala and Contemporary Igbo Families" In J.I Okonkwo (ed.) Journal of Nigerian Language and Culture Owerri: Association of Promoting Nigerian Languages and Culture. Vol. 6. pp. 98 102.

Eme, C.A (2004). "Improving Igbo Language use at Homes and Communities" In P.C. Nzomiwu and J.E. Madu (eds.) Unizik Journal of Arts and Humanities. Awka; A Global Communications Production. Vol. V. pp. 302-313.

Fishman, J.A. (2001). "Why is it so hard to save a threatened languages? Reversing language Shift Revisited: A $21^{\text {st }}$ Century Perspective. Clevedan: Multilingual Matters.

Grimes, B.F. (2000). Ethnologue: Languages of the World. Fourteenth edition. SIL International.

Heine, B. and D. Nurse (2000). African Languages: An Introduction. Cambridge: Cambridge University Press.

Irono, C.B. (2005). "Insurance of Culture". In J.I. Okonkwo (ed). Journal of Nigerian Language and Culture. Owerri: Association for Promoting Nigeria Languages and Culture, pp. 30-35. 
National Policy on Education (1981).

Nwadike, I.U. (2008). "Igbo Langauge and Culture! Whither Bound! (Asusu na Omenala Igbo: Ije Anaa?) In R.N. Umeasiegbu (ed.) Chief (er.) F.C Ogbalu Memorial Lecturers ( $\&$ 3). Onitsha Vasity Puiblishing Co. Ltd. In Association with Nnamdi Azikiwe University, Awka pp. 5-59.

Othman, A. and A. Bashir (2000). "Language Choice and Use in Maiduguri" In S.B. Ajulo and the Festschrift Committee (eds.) Language in Society: Festschrift in Honour of Professor Conrad Max Benedict Brenn. Lagos: University of Lagos Press.

Wassink, A.B. (1999). "Historic Low Prestige and Seeds of Charge" Attitudes Toward Jamaica Creole". In W. Bright (ed.). Language in Society. Cambridge: Cambridge University Press. Vol. 28. No. 1 pp. 57-92. 